\title{
Use of Eichhornia crassipes dry matter as organic substrate for germination and initial growth of corn
}

\section{Uso de la materia seca de Eichhornia crassipes como sustrato orgánico para la germinación y crecimiento temprano del maíz}

\author{
Mariane Luz dos Anjos ${ }^{1}$, Jaqueline Aparecida Bória-Fernandez ${ }^{2}$, Matheus Nicolino Peixoto-Henares ${ }^{2 *}$ \\ ${ }^{1}$ Universidade Estadual Paulista Júlio de Mesquita Filho, Faculdade de Engenharia de llha Solteira, llha Solteira, Avenida Brasil \\ Centro, 56, São Paulo, Brasil. \\ ${ }^{2}$ Centro Universitário da Fundação Educacional de Barretos - UNIFEB, Avenida Professor Roberto Frade Monte N 389, CEP \\ 14783-226, Barretos, São Paulo, Brazil. \\ ${ }^{*}$ Corresponding author: henaresmnp@gmail.com
}

Scientific note received: 24 de junio de 2016 accepted: 26 de junio de 2017

\begin{abstract}
The objective was to evaluate the potential use of the dry matter of the aquatic macrophyte (Eichhornia crassipes) as a substrate for germination and initial growth of corn (Zea mays L.). The experimental design was completely randomized with four treatments and five replicates. The treatments consisted of testing substrates with different levels of $E$. crassipes dry matter and agricultural soil mixtures, with $100 \%$ E. crassipes dry matter, $50 \% E$. crassipes dry matter and 50\% agricultural soil, 25\% E. crassipes dry matter and $75 \%$ agricultural soil, and $100 \%$ commercial agricultural substrate. Average stem height and diameter, and shoot and root fresh and dry mass were compared by one-way ANOVA and Tukey's test $(p<0.05)$. The results showed that $E$. crassipes dry matter could be used as a substrate for the germination and initial growth of corn, although the commercial agriculture substrate alone has resulted in higher initial corn growth
\end{abstract}

Key words: Biomass, aquatic macrophyte, nutrients, soil, agriculture, Zea mays L.

RESUMEN. El objetivo del estudio fue evaluar el uso potencial de la materia seca de los macrófitos acuáticos (Eichhornia crassipes) como un sustrato para la germinación y el crecimiento de maíz (Zea mays L.). El experimento se realizó con cuatro tratamientos y cinco repeticiones en un diseño completamente al azar. Los tratamientos consistieron en mezclas de materia seca de la maleza y el suelo agrícola, con $100 \%$ de macrófitos, $50 \%$ de la E. crassipes y $50 \%$ de tierra agrícola, $25 \%$ de E. crassipes y $75 \%$ de tierra agrícola y un sustrato comercial al $100 \%$. Se avaluó altura media, diámetro, peso fresco de la parte aérea, peso fresco de las raíces, peso seco del vástago y la raíz, y peso seco del tallo mediante ANOVA de una vía y la prueba de Tukey $(\mathrm{p}<0.05)$. Los resultados indican que la materia seca de $E$. crassipes se puede utilizar como sustrato para la germinación, aunque el sustrato comercial tuvo un mayor crecimiento inicial de maíz.

Palabras clave: Biomasa, macrófitos acuáticos, nutrientes, suelo, agricultura, Zea mays L.

\section{INTRODUCTION}

Aquatic plants (macrophytes) play an important role in the structure and function of aquatic ecosystems (Chambers et al. 2008, Mormul et al. 2010). Eichhornia crassipes (Mart.) Solms, Pontederiaceae is a perennial floating macrophyte, native to the tropical Americas. In some areas where $E$. crassipes was introduced, it has become a problem due to obstruction of waterways preventing navigation and water capture for various purposes (Bortolotto and Neto 2005). The excessive growth of these plants may be due to the release of effluents resulting from human activities, which increase the amount of nutrients in receptor water bodies, providing favorable conditions for their development 
(Páez-Osuna et al. 1997). In Brazil, unwanted proliferation of macrophytes has been reported in hydroelectric dams and environments impacted by the release of wastewater from domestic, industrial and aquaculture activities (Marcondes et al. 2003, Pistori et al. 2010).

Macrophyte overgrowth has led to increasing interest in investigating the potential use of this biomass. Several studies have reported the use of macrophyte biomass as a carbohydrate and protein source in animal feed (Henry-Silva et al. 2006, Biudes et al. 2009) and nutrients removal of organic effluents (Henry-Silva and Camargo 2008, Henares and Camargo 2014). The use of macrophytes as fertilizer and organic fertilizer was reported by Sampaio and Oliveira (2005) and Bezerra et al. (2007).

Agriculture, like any other agricultural activity, undergoes constant innovation to improve productivity. In this context, the use of agrochemicals to control pests and to obtain more fertile soils and more productive crops are highlighted. However, the use of agrochemicals to increase productivity can lead to pollution of soil and surface and groundwaters. In Brazil, corn and soybean contribute about $80 \%$ of grain production (FAO 2014). An alternative to reduce the use of chemical fertilizers in corn crops may be to use the biomass of aquatic macrophytes as a substrate for plant growth. Macrophyte organic matter, when incorporated into the soil, may alter the physical, chemical and biological properties of the soil and eventually change soil fertility. Given the above, we hypothesized that using $E$. crassipes dry matter could favor corn germination and growth due to the nutrients incorporated into the macrophyte biomass. A $25 \mathrm{~d}$ experiment using $E$. crassipes dry matter as a substrate for germination and initial growth of corn (Zea mays L.) was conducted to test this hypothesis.

\section{MATERIALS AND METHODS}

The use of $E$. crassipes dry matter as substrate for corn germination and initial growth was evaluated using a completely randomized experimental design with four treatments and five replicates, in a greenhouse in Barretos, SP, Brazil (203' 33" South and 48 34' 8" West). According to Köppen, the region has an Aw-type climate, with mild and dry winters and hot and rainy summers.

The treatments consisted of mixing different levels of $E$. crassipes dry matter and agricultural soil. The following treatments were tested: 1) the substrate consisted of $100 \%$ aquatic macrophyte ( $E$. crassipes) dry matter (Am); 2) 50\% E. crassipes dry matter and 50\% agricultural soil (AmAs); 3) 25\% E. crassipes dry matter and $75 \%$ commercial agricultural substrate (AAs); and 4) $100 \%$ commercial agricultural substrate (CAS). The substrates with macrophytes (Am, AmAs and AAs) were prepared by mixing the plant's parts and roots. Table 1 shows the ratios of the substrates.

Table 1. E. crassipes dry matter and commercial agricultural ratios used in the substrate.

\begin{tabular}{lll}
\hline Treatments & $\begin{array}{l}\text { Dry matter }(\mathrm{g}) \\
\text { Eichhornia Crassipes }\end{array}$ & Soil \\
\hline Am & 12 & - \\
AmAs & 6 & 75.0 \\
AAs & 3 & 75.0 \\
CAS & - & - \\
\hline
\end{tabular}

The $E$. crassipes used in the experiment came from the macrophyte collection of the Agricultural Sector of the Centro Universitário da Fundação Educacional de Barretos (UNIFEB), SP. Table 2 shows the physicochemical parameters of the water in the macrophyte maintenance tank. The selected macrophytes had similar sizes and appearance. The plants were washed to remove solids adhered to the biomass, cut and placed on metal trays, which were subsequently placed in an oven at $60{ }^{\circ} \mathrm{C}$ until constant weight. The dried plants were then crushed in a mill (model Willye Te-650) and weighed on a semi-analytical balance (Model Shimadzu 3200HL BL) to obtain the dry matter mass $(\mathrm{g})$.

The agricultural soil used in the AmAs and AAs treatments was collected in an UNIFEB area with no agricultural activities. The soil is classified as Oxisoil with the following chemical properties at 0.20 m deep: $\mathrm{pHCaCl}_{2}=4.0$; organic matter - OM 
Table 2. Means $(n=3)$ and standard deviation of water parameters: temperature (temp.), $\mathrm{pH}$, dissolved oxygen (DO), electrical conductivity, total Kjeldahl nitrogen (TKN) and total phosphorus (TP) in the Eichhornia crassipes tanks.

\begin{tabular}{ccccccc}
\hline $\begin{array}{c}\text { Physico- } \\
\text { chemical } \\
\text { parameters }\end{array}$ & Temp. $\left({ }^{\circ} \mathrm{C}\right)$ & $\mathrm{pH}$ & $\mathrm{DO}\left(\mathrm{mg} \mathrm{L}^{-1}\right)$ & $\begin{array}{c}\text { Electrical } \\
\text { conductivity } \\
\left(\mathrm{mS} \mathrm{cm}^{-1}\right)\end{array}$ & TKN $\left(\mathrm{mg} \mathrm{L}^{-1}\right)$ & TP $\left(\mu \mathrm{g} \mathrm{L}^{-1}\right)$ \\
\hline $\begin{array}{c}\text { Tanks } \\
\text { with } \\
\text { macrophytes }\end{array}$ & $27.1 \pm 0.61$ & $7.9 \pm 0.4$ & $6.0 \pm 0.6$ & $0.094 \pm 0.023$ & $0.50 \pm 0.12$ & $205.0 \pm 29.1$ \\
\hline
\end{tabular}

Table 3. Means $(n=5) \pm$ standard deviation of the parameters height $(H)$; stem diameter (SD), shoot fresh mass (FMsh), root fresh mass (FMro), shoot dry matter (DMsh) and root dry matter (DMro).

\begin{tabular}{ccccccc}
\hline \multirow{2}{*}{ Treatment } & \multicolumn{7}{c}{ Variables } \\
\cline { 2 - 7 } & $\mathrm{H}(\mathrm{cm})$ & $\mathrm{SD}(\mathrm{mm})$ & FMsh $(\mathrm{g})$ & DMsh $(\mathrm{g})$ & FMro $(\mathrm{g})$ & DMro $(\mathrm{g})$ \\
\hline Am & $24.9 \pm 1.6^{b}$ & $0.32 \pm 0.03$ & $0.86 \pm 0.13^{b}$ & $0.25 \pm 0.20^{b}$ & $4.20 \pm 0.6$ & $1.82 \pm 0.61$ \\
$\mathrm{AmAs}$ & $27.3 \pm 2.3^{b}$ & $0.32 \pm 0.0$ & $1.02 \pm 0.11^{b}$ & $0.17 \pm 0.15^{b}$ & $3.17 \pm 1.3$ & $1.34 \pm 0.85$ \\
$\mathrm{AAs}$ & $27.5 \pm 5.6^{b}$ & $0.26 \pm 0.03$ & $0.28 \pm 0.12^{c}$ & $0.21 \pm 0.04^{b}$ & $3.38 \pm 0.8$ & $2.24 \pm 0.45$ \\
CAS & $39.0 \pm 8.5^{a}$ & $0.35 \pm 0.0$ & $1.83 \pm 0.20^{a}$ & $0.58 \pm 0.20^{a}$ & $4.83 \pm 1.2$ & $1.72 \pm 0.23$ \\
ANOVA P value & $<0.0001$ & 0.186 & $<0.0001$ & $<0.0001$ & 0.076 & 0.44 \\
ANOVA F value & 31.3 & 1.8 & 29.2 & 10.80 & 2.75 & 0.95 \\
\hline
\end{tabular}

$\left(\mathrm{g} \mathrm{dm}^{-3}\right)=12.0 ; \mathrm{P}\left(\mathrm{mg} \mathrm{dm}^{-3}\right)=3.0 ; \mathrm{K}, \mathrm{Ca}, \mathrm{Mg}$, $\mathrm{H}+\mathrm{Al}, \mathrm{SB}$ and $\mathrm{CTC}\left(\mathrm{mmol} \mathrm{dm} \mathrm{m}^{-3}\right)=1.9 ; 4.0 ; 1.7$; $48.6 ; 7.6 ; 56.2$, respectively, and $14 \%$ base saturation ( $\mathrm{Ca}, \mathrm{Mg}$ and $\mathrm{K}$ ).

Conventional corn seeds were provided by the UNIFEB Soil Laboratory. Three corn seeds were planted in the substrates in germination tubes (100 $\mathrm{cm}^{-3}$ ), which were placed in plastic trays inside the greenhouse. The temperature was maintained at $27 \pm 2{ }^{\circ} \mathrm{C}$ and relative humidity $(\mathrm{RH})$ at approximately $85 \%$. After germination, the lower growth seedlings were cut to avoid competition between individuals and ensure better development of the remaining seedlings.

Seedling growth $(\mathrm{H}, \mathrm{cm})$ and stem diameter $(\mathrm{SD} \mathrm{cm})$ were measured every $3 \mathrm{~d}$ from the tenth day of planting using a graduated ruler and caliper, respectively. At the end of the experiment, the seedlings were removed from substrates, carefully washed and dried on paper towels to determine the fresh mass ( $\mathrm{g}$ ) of the shoots (FMsh) and roots (FMro). The seedlings were then placed in metal trays to obtain shoot (DMsh) and root (DMro) dry matter (g) following the methodology previously described.

\section{Statistical analysis}

The growth parameters stem diameter and fresh and dry matter were subjected to descriptive statistics and, subsequently, to the KolmogorovSmirnov and Bartlett test to verify the normality and equality of variances (homoscedasticity), respectively. The one-way analysis of variance (oneway ANOVA) was applied to the stem diameter and fresh and dry mass data. The repeated measures ANOVA was used to assess the effects of the treatments (Am, AmAs, AAs and CAS) on seedling growth in the different evaluation periods (days). The means were compared by Tukey's test $(p<$ 0.05).

\section{RESULTS AND DISCUSSION}

The initial hypothesis of the study was partially confirmed. The seeds germinated in all treatments six days after planting. At the end of the experiment (25d), the stem diameter (SD) and root fresh (FM) and dry matter (DM) of corn seedlings were not significantly different $(p<0.05)$ between treatments (Table 3). Regarding aerial plant parts, ANOVA showed that shoot FM and DM were significantly higher in the CAS treatment. Moreover, shoot fresh mass was on average 1.8, 2.1 and 6.5 times higher than that of the Am, AmAs and AAs treatments, respectively (Table 3 ). Seedling height in commercial agricultural soil $(39.0 \mathrm{~cm})$ was on 
Table 4. Means $(n=5)$ ( \pm standard deviation) for corn (Zea mays L.) seedling height and results of repeated measures ANOVA. Values of $\mathrm{P}$ for effects of treatments (Tr.), time (Te.) and treatment vs. time interaction (Tr. $\mathrm{XTe}$.).

\begin{tabular}{|c|c|c|c|c|c|c|}
\hline & \multirow{2}{*}{ Am } & \multirow{2}{*}{ AmAs } & \multirow{2}{*}{ AAs } & \multirow{2}{*}{ CAS } & \multicolumn{2}{|c|}{ Repeated measures ANOVA ( $P$ values) } \\
\hline & & & & & Te. & Tr. X Te. \\
\hline $\mathrm{H}(\mathrm{cm})$ & $24.9 \pm 1.6^{b}$ & $27.3 \pm 2.3^{b}$ & $27.7 \pm 5.6^{b}$ & $39.0 \pm 8.5^{a}$ & $<0.0001$ & $<0.0001$ \\
\hline
\end{tabular}

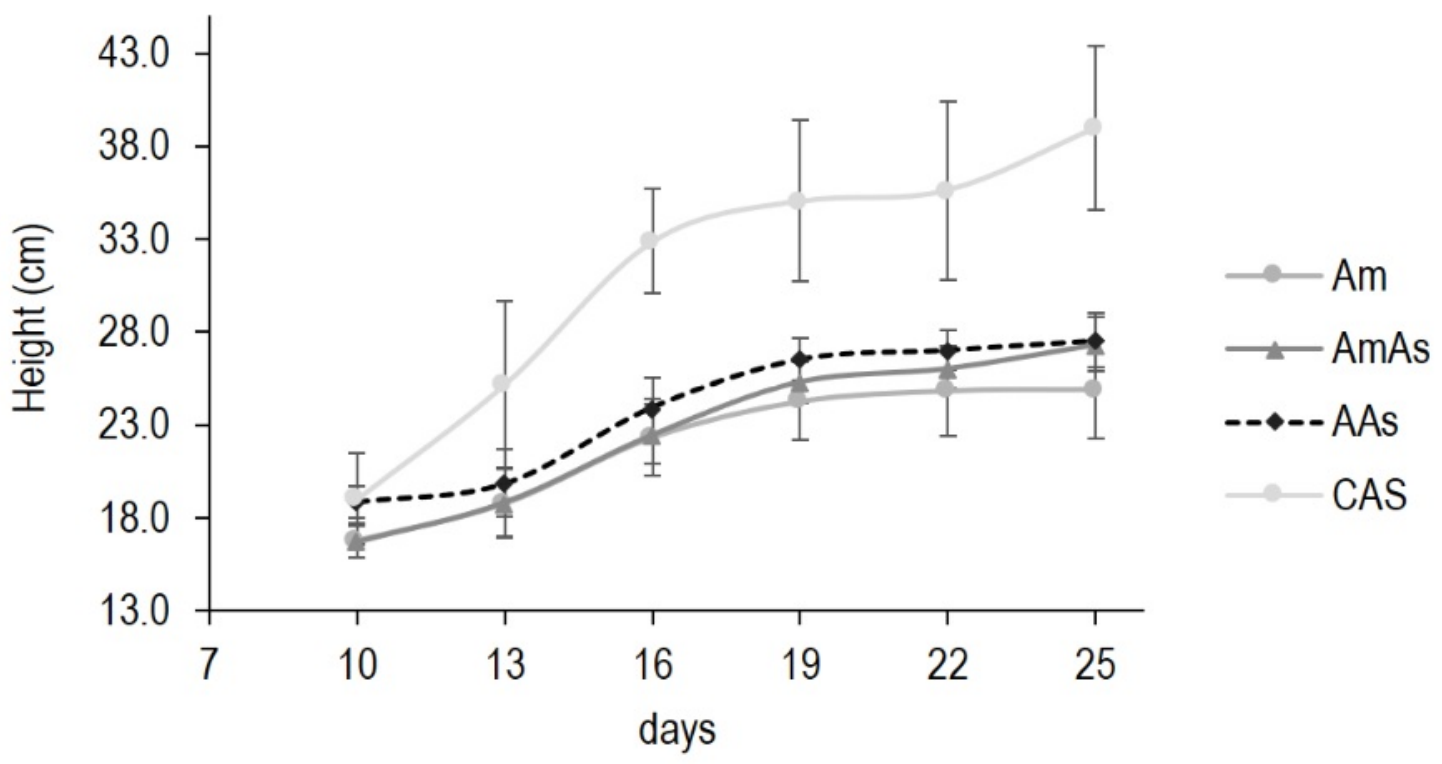

Figure 1. Growth curves (means and standard deviation) of corn seedlings planted in four different substrates: macrophyte only (Am); $50 \%$ macrophyte and $50 \%$ agricultural soil (AmAs); $25 \%$ macrophyte and $75 \%$ agricultural soil (AAs); and commercial agricultural substrate only (CAS).

average $46.6 \%$ higher compared to the other treatments (26.6 cm on average) (Table 3 ).

The repeated measures ANOVA showed significant difference $(p<0.05)$ between treatments, time (days), and treatment vs. time interaction (Table 4). Corn seedling growth was significantly ( $p<$ 0.05) higher in the CAS treatment. Substrates with macrophytes (Am, AmAs, and AAs) did not result in significantly different growth rates for corn (Table 3 ). This result suggests that $E$. crassipes dry matter can be used as a component of the substrate, but further studies are needed to determine the best mixture ratio ( $E$. crassipes dry matter and agricultural soil).

Figure 1 shows that average corn seedling height was lower $(26.6 \mathrm{~cm})$ in the macrophyte treat- ment compared to the commercial agricultural soil $(39.0 \pm 8.5 \mathrm{~cm})$, at the end of the experiment. The seedlings planted in the substrates with $E$. crassipes probably absorbed nutrients from the dry matter (i.e., nutrients incorporated into the $E$. crassipes biomass). According to Malavolta et al. (1989), the nutrients absorbed by the macrophytes are incorporated into the soil allowing the nutritional requirements of the plants to be met. However, the lower average corn seedling height reached in the treatments with macrophytes (Am, AmAs and AAs) might be related to low nutrient concentrations present in E. crassipes dry matter since the macrophytes originated from an environment with average TN and TP concentrations of $0.50 \mathrm{mg} \mathrm{L}^{-1}$ and 205 $\mu \mathrm{g} \mathrm{L}^{-1}$, respectively. Probably, E. crassipes that 
originate from aquatic environments with higher nutrient concentrations also have higher nitrogen and phosphorus concentrations in their biomass. Thus, the use of plant biomass from eutrophic and hypereutrophic environments should be considered because a larger stock of nutrients in the macrophyte biomass might enrich the planting substrate. In addition to incorporating nutrients to the soil, the removal of macrophytes from environments impacted by human activities may represent a management strategy of unwanted infestations of aquatic weeds.

The dry matter of aquatic macrophytes can be used as a substrate in agriculture, as reported by Sampaio and Oliveira (2005). These authors reported that the Egeria densa biomass removed from the Paulo Afonso hydroelectric reservoir was incorporated into the soil. The plant biomass increased the amount of nutrients in the soil, which resulted in a corn yield increase from $4.2 \mathrm{tha}^{-1}$ in (soil fertilized with cattle manure) to $7.7 \mathrm{t} \mathrm{ha}^{-1}$ (soils with macrophyte). The continuous use of organic fertilizer increased corn productivity compared to chemical fer- tilizer, as reported by Maia and Cantarutti (2004).

The greater growth observed in the CAS treatment is probably due to the increased availability of micro and macronutrients in the commercial agricultural substrate. Although the CAS treatment displayed better results in early corn growth, Farias et al. (2013) suggest the use of $E$. crassipes as a substrate for germination and initial seedling growth due to the high $\mathrm{C} / \mathrm{N}$ ratio observed in the macrophyte biomass.

The commercial agricultural soil performs better during initial corn growth. The $E$. crassipes dry matter can be used as substrate for corn germination and initial growth; however, further studies are necessary to determine the macrophyte DM/agricultural soil ratio that can optimize corn germination and initial growth.

\section{ACKNOWLEDGEMENTS}

We are grateful to the Institutional Program of Scientific Initiation (PIBIC) of Centro Universitário da Fundação Educacional de Barretos (UNIFEB) for providing fellowships for the first author.

\section{LITERATURE CITED}

Bezerra TP, Silva CP, Lopes JP (2007) Utilização da macrófita aquática Egeria densa PLANCHON, 1849 (Hydrocharitacea) na produção de tijolos para a construção civil. Revista Brasileira de Engenharia Pesca 2: $113-127$.

Biudes JFV, Pezzato LE, Camargo AFM (2009) Digestibilidade aparente da farinha de aguapé em tilápiasdo-nilo. Revista Brasileira de Zootecnia 38: 2079-2085.

Bortollotto IM, Neto GG (2005) O uso de camalote, Eichornia crassipes (Mart. Solms), Pontederiaceae, para confecção de artesanato do Distrito de Albuquerque, Corumbá, MS, Brasil. Acta Botanica Brasilica 19: 331-337.

Chambers PA, Lacoul P, Murphy KJ, Thomaz SM (2008) Global diversity of aquatic macrophytes in freshwater. Hydrobiologia 595: 9-26.

Farias WM, Andrade LA, Pereira ED, Dias BO, Albuquerque MB, Fraga VS (2013) Propriedades físicas e químicas de substratos produzidos utilizando macrófitas aquáticas. Semina: Ciências Agrárias 34: 3257 - 3270.

FAO (2014) Estimating of Agriculture Production (2012-2014). Food and Agriculture Organization of the United Nations. 2014. http://faostat.fao.org/site/339/default.aspx. Data consulted: October 3, 2014.

Henares MNP, Camargo AFM (2014) Estimating nitrogen and phosphorus saturation point for Eichhornia crassipes (Mart.) Solms and Salvinia molesta Mitchell in mesocosms used to treating aquaculture effluent. Acta Limnologica Brasiliensia 26: 420-428. 
Henry-Silva GG, Camargo AFM (2006) Composição química de macrófitas aquáticas flutuantes utilizadas no tratamento de efluentes de aquicultura. Planta Daninha 24: 21-28.

Henry-Silva GG, Camargo AFM, Pezzato LE (2006) Digestibilidade aparente de macrófitas aquáticas pela tilápia do nilo (Oreochromis niloticus) e qualidade da água em relação às concentrações de nutrientes. Revista Brasileira de Zootecnia 35: 642-647.

Henry-Silva GG, Camargo AFM (2008) Tratamento de efluentes de carcinicultura por macrófitas aquáticas flutuantes. Revista Brasileira de Zootecnia 37: 181-188.

Maia CE, Cantarutti RB (2004) Acumulação de nitrogênio e carbono no solo pela adubação orgânica e mineral contínua na cultura do milho. Revista Brasileira de Engenharia Agrícola e Ambiental 8: 39-44.

Malavolta E, Malavolta ML, Cabral CP, Antoniolli F (1989) Sobre a composição mineral do aguapé Eichhornia crassipes. Anais da Escola Superior de Agricultura Luiz de Queiroz 46: 155-162.

Marcondes DAS, Velini ED, Martins D, Tanaka RH, Carvalho FT, Cavenaghi AL, et al. (2003) Eficiência de fluridone no controle de plantas aquáticas submersas no reservatório de Jupiá. Planta Daninha 21: 69-77.

Mormul RP, Ferreira FA, Michelan TS, Carvalho P, Silveira MJ, Thomaz SM (2010) Aquatic macrophytes in the large, sub-tropical Itapipu Reservoir, Brazil. Revista de Biologia Tropical 58: 1437-1452.

Páez-Osuna F, Guerrero-Galván SR, Ruiz-Fernández AC (1997) The environmental impact of shrimp aquaculture and the coastal pollution in México. Marine Pollution Bolletin 36: 65-75.

Pistori RET, Henry-Silva GG, Biudes JFV, Camargo AFM (2010) Influence of aquaculture effluents on the growth of Salvinia molesta. Acta Limnologica Brasiliensia 22: 179-186.

Sampaio EVSB, Oliveira NMB (2005) Aproveitamento da macrófita aquática Egeria densa como adubo orgânico. Planta Daninha 23: 169-174. 